\title{
El caso de las publicaciones pornográficas y su acceso a niños y adolescentes en México.
}

\section{Carta al Editor}

Jesús Quintanilla-Osorio.

Servicios Estatales de Salud de Quintana Roo. Coordinación de Regulación Sanitaria. Chetumal, Quintana Roo, México.

Es innegable en cualquier legislación que se precie de serlo, la garantía de expresarse libremente y sin cortapisas no existiendo nada que pueda medrar este derecho.

En la legislación mexicana, el artículo séptimo de la Constitución Política, permite al ciudadano común, expresarse libremente y bajo la protección del estado, siempre y cuando no vulnere los derechos de terceros, porque entonces, si existe la probatoria de incurrir en un acto doloso que pueda afectar a un ciudadano, este puede esgrimir en su defensa, la denuncia por difamación de honor.

Sin embargo, aunque la Ley de Imprenta ha garantizado la libre publicación de los escritos, con la salvaguarda de ser protegido el derecho de expresión, se cuestiona la legitimidad de publicaciones que, utilizando gráficos de dibujos animados conocidos por los niños por ser los héroes de caricaturas con amplia difusión en las televisoras de cobertura nacional, fomentan la pornografía que está al alcance de los menores de edad, y normalmente, la responsabilidad recae directamente en los padres que deben orientar a los pre-adolescentes sobre los temas sexuales, mientras la Secretaría de Gobernación, que regula la salida de estas publicaciones, debe atenerse al cuerpo de la Ley y sujetarse a que la edad legal en México, es de 18 años.

La leyenda precautoria de "Venta restringida a mayores de 18 años" es obligatoria en las revistas de corte sexual, pero debe ser fortalecida con la responsabilidad del vendedor, para negar su adquisición a las personas que no reúnan el requisito legal, como es la minoría de edad.

La libertad de pensamiento está sujeta a los valores de una sociedad regida por principios morales que no deben ser abandonados bajo ninguna causa, porque la vigencia misma de la existencia de la comunidad, se basa en el fortalecimiento de la familia como base de la estructura orgánica. La posibilidad de desestabilizar a los miembros más jóvenes de este núcleo con información para la que no están preparados, ocasiona severos problemas psicológicos, que deberían ser atendidos por los padres del menor con información clara y detallada sobre el tema sexual, para no resultarles tentadoras este tipo de publicaciones. Mientras, el estado debe articular una

Solicitud de sobretiros: Jesús Quintanilla-Osorio. Tlaxcalaltongo No. 250 entre Carranza y San Salvador, Col. Carranza. Chetumal, Quintana Roo, México. E-mail: jesusin06_@hotmail.com

Aceptado para publicación 28/Octubre/2002 


\section{J Quintanilla-Osorio.}

vigilancia estricta para hacer cumplir la Ley, sancionando a quienes permitan la libre venta de este material pornográfico a quienes no ostenten la edad legal para su adquisición. De otro modo, el fortalecimiento de publicaciones pornográficas sin la vigilancia del estado, viola los principios morales bajo los cuales está sostenida nuestra civilización occidental.

Palabras clave: pornografía, educación, México. 